\title{
Bridging the Gap in Teacher Education Curriculum in Promoting Entrepreneurship: A Case Study of Undergraduate Students of Kwame Nkrumah University, Kabwe-Zambia
}

\author{
Lefterius Kalonga Mwamba ${ }^{1}$, Astridah Musonda $-\mathrm{PhD}^{2}$ and Harrison Daka $-\mathrm{PhD}^{3}$ \\ ${ }^{1},{ }^{2}$ Kwame Nkrumah University, Department of Education \\ ${ }^{3}$ The University of Zambia, Department of Educational Administration and Policy Studies
}

\begin{abstract}
The purpose of this study was to investigate how teacher education curriculum of undergraduate students of tertiary education institutions promotes entrepreneurship. The study was guided by the following specific objective to examine the extent to which entrepreneurship education is being practiced at Kwame Nkrumah University, to discover how the teacher education curriculum being used at Kwame Nkrumah University is being used to promote entrepreneurship culture. This case study was anchored on pragmatism as its research paradigm; it used a mixed method approach and employed the concurrent triangulation design. The study used simple random sampling on students, random sampling for Lecturers and purposive sampling for Administrator. Data collection instruments were questionnaires and interview guides and analysed data was eventually presented if form of frequency tables, bar graphs and pie charts. The study's findings are that majority of students of Kwame Nkrumah University are aware of the importance of mentorship in entrepreneurship and are willing to acquire entrepreneurial skills, only a minority of students who belong to the category of business studies formally have access to the said mentorship and that this mentorship is merely theoretical. The study also established that the curriculum in application for training of students is as a matter of fact not inclusive in the provision of mentorship in entrepreneurship and that there is a missing link between the secondary and the tertiary education in the provision of the aforementioned mentorship. In view of building the gap in promoting in entrepreneurship at the university and in other similar institutions of tertiary education, the study has recommended curriculum revision.
\end{abstract}

Key Words: Promotion, Entrepreneurship and Curriculum

\section{INTRODUCTION}

$\mathrm{S}$ ince Zambia's independence in 1964, the Ministry in charge of Education has undertaken a number of major education policy reforms in its quest to improve the quality of education for learners at different levels. In the year 1996 saw the adoption of the new TEVET policy which incorporated and mainstreamed entrepreneurship. This new policy aimed at providing a national system of TEVET that would meet the demands of opportunities in the economy through an attempt to balance the supply of skilled labor at all levels with the demands of the economy, to act as a vehicle for improved productivity and income generation and to be an instrument for the minimization of inequalities among the people (ZECFR, 2013). Consequently, there is a development of two career streams, which are: academic and vocational in Zambia's secondary education leading to the Trades Training.

In was revealed that in 2014, more than $80 \%$ of the employed in Zambia were in the informal sector (GRZ, 2018). However, the sector was characterized by low levels of productivity, capital investments and technology, thereby offering limited prospects to contribute to national development and ultimately improving the standard of living of the majority of the people. The Zambia Educational Curriculum Framework of 2013 reechoed the importance of the element of entrepreneurship to an education system. From the preparation of the Zambia Education Curriculum Framework 2013, it is evident that to some extent, the Ministry of Education has recognised the importance of entrepreneurship to individuals, the youth and society. This is mostly reflected in the secondary school curriculum and in the Technical Education, Vocational and Entrepreneurship Training (TEVET).

However, an important concern would be how to find a way through which all stakeholders, including policy makers, educators, individuals and employers can resolve the problem of this missing link between entrepreneurship skills education at secondary school level and at University level. It is of great importance to further explore mentorship of students in entrepreneurship, to critically analyse it and assess the extent to which its application may be relevant to the attainment of the eighth Sustainable Development Goal in particular and sustainable development in general. Therefore, it is against this background that this thesis attempts to investigate the missing gap in teacher education curriculum in promoting entrepreneurship at Kwame Nkrumah University of central Zambia. 


\section{Statement of the Problem}

According to the Central Statics Office records of the year 2017, the working age population in Zambia covers about $55.2 \%$ of the total projected population for the year. This is as seen in the Central Statistics Office (GRZ, 2018) records of the year 2017. This implies that this set of population is the majority. It is revealed that in Zambia, many young people are finding themselves unemployment due to lack of work experience and their being unable to gain work experience due to lack of employment. This clearly shows that the rate of unemployment is high and that it is one of the biggest challenges that the country is facing vis-àvis development. In this vein, it is significant to pay attention to how tertiary education institutions can bridge this missing gap in teacher education to promote entrepreneurship in an attempt to help solve the problem of high unemployment among the educated youth population.

\section{Theoretical Concept}

The research conducted was guided by the Human Capital Theory (HCT). The theory suggests that individuals and society derive economic benefits from investment in people and in this typology of investment, education emerges as a prime human capital investment for empirical analysis (Becker, 1993). This implies that education, to the extent of this context, is the modus operandi for investment in human capital. Considering a critical analysis of the HCT, we may arrive at an affirmation that the theory is a frame work that examines the relationship between education, economic growth, and social wellbeing. It posits that expenditure on education, job training and health care are capital investments that will yield economic and social returns at the individual and social levels. In the same line of thought, Netcoh (2016) adds that education and training are assumed to lead to greater productivity which is ultimately translated into economic returns such increased Gross Domestic Product (GDP) and higher wages. More so, Sweetland (1996) notes that the HCT as applied to education has paralleled a powerful paradigm created by the general public which assumes that the pursuit of education leads to individual and national economic growth. This means that education becomes the major determinant of economic growth. It may also help them design educational programmes (such as entrepreneurship education) that contribute to economic growth without compromising educative purposes and to clearly define the economic component of education. Subsequently, the HCT increases productivity.

\section{Missing gap in Teacher Education in Promoting Entrepreneurship}

Some researchers have argued that entrenching entrepreneurship education as a curriculum issue has been a problem. Uthman (2016) has highlighted some of the challenges: the primary obstacle is that there is lack of lecturers with practical entrepreneurial training and consciousness. Uthman continues to argue that majority of the lecturers still do not have enough knowledge about the aims, contents and work method of entrepreneurship education. Consequently, this hinders the effective imparting of desired knowledge and entrepreneurial skills to students. In some African countries such as Nigeria, the following challenges have been found to be a hindrance to the development of entrepreneurship education: the need for substantial funds, inadequate equipment and technology, entrepreneurial attitude, lack of data on entrepreneurship education and inadequate infrastructure (Unachukwu, 2009).

In the case of Zambia, Konayuma (2009) points out a number of challenges being faced in the provision of entrepreneurial education such as: inadequate entrepreneurship trainers, lack of appropriate training materials, lack of appreciation of entrepreneurs and a poor entrepreneurial culture. Explicatively, we may deduce that entrepreneurship education is a capital intensive process and both lecturers and students need money to practice the theory of initiating, establishing and running enterprises. This, undoubtedly constitute constraints which subsequently frustrate the integration of the entrepreneurship in academic programmes in most universities (Uthman, 2016).

It is revealed that in Zambia many young people are finding themselves unemployed due to lack of work experience. Lack of work experience is also a common complaint by employers when looking to hire new employees (Go Zambia Jobs, 2018). This as a matter of fact refers to the competitiveness of the job market to which graduates are exposed. Further analyzing this, we may understand that lack of job opportunities is the credo of the aforementioned challenges. And if there are no job opportunities, it implies that there will be less or no possibilities of gaining work experience, which is presented as a key requirement for the job industry.

In some countries like Zambia, it is rare to note government supporting graduates to integrate into the larger society. However, this does not absolutely state that the government is effortless towards such an issue. There are some policies that are in place with an objective to financially empower youths and citizens at large. For example, there is the youth empowerment fund and the citizen empowerment fund. The outcry on the access to the aforementioned funds is that of bureaucracy. Some youths and citizens barely manage to access the funds.

The challenges discussed above may be translated into poor social economic welfare of graduates and this implies poverty. This may consequently result into high crime rates and moral decadence among youths, but if the said graduates where to be adequately equipped with entrepreneurial skills, they would be capable of creating jobs and thereby contributing positively to society. 


\section{Bridging the Gap in Teacher Education Curriculum in Promoting Entrepreneurship}

Stressing technology's importance will enhance entrepreneurship in that mentors need to explain how strategic businesses use technology to communicate, market, innovate and ultimately earn a profit. Gimmon (2014) and Daka (2018) add that current generations are very knowledgeable when it comes to technology, but it is not always entrepreneurship oriented, hence the need to teach students strategic ways companies and entrepreneurs are using technology to make money.

Clutterbuck (2009:89) argues that "participating in entrepreneurship contests is a great opportunity for students to put their knowledge to practice and meet students from other schools and exchange experience, learn how other institutions teach in the case of mentors." Besides that, competitiveness also needs practice and development since the business world can be deemed a huge competition. Clutterbuck (2009) emphasizes that mentors need to enroll in entrepreneur-inresidence programs to enhance their creativity, critical thinking and competitiveness. He furthers argues this allows mentors to provide support and enthusiasm to the students besides all the constructive feedback or advice that they can give. The afore-mentioned programs are meant to educate and update mentors on changes made in the curriculum. Eventually, both mentors and students would take advantage of situation simulations. It is further argued that such programs shape entrepreneurial thinking and help use the knowledge gained from lecturers and books in practice. Orientations towards entrepreneurship among students may be dependent on their adaptive skills and ability to effectively navigate through unanticipated transitions and risk inherent entrepreneurship. Henceforth, behavior modifications towards enhancing these traits may substantially be beneficial in encouraging entrepreneurship among students.

Some scholars have proposed a number of models which they think would promote effective mentorship in entrepreneurship. Gibb (2008) proposes that in order for mentorship in entrepreneurship to be embedded into the education system, it should be child centered in primary [education], subject centered in secondary [education], vocational centered in further education and discipline centered at university. Based on this, Gibb also put up an evaluation framework linking this progression model to eight allegedly testable learning outcomes for each of the four levels of education. For Gibb, these learning outcomes consist of different variations on entrepreneurial competencies. He provides some example exercises and evaluation methods that could inspire teachers, such as asking learners to explain what the use of some particular piece of knowledge might be to whom and why.

Lackéus (2015) has also proposed a progression model that outlines four different types of action-based pedagogy. According to this model, increasing complexity in the creation process could be introduced the higher up in the educational system you get. This can help teachers determine which class of activity to opt for in any given teaching situation depending on purpose, ability, resource access, interest and context. According to this classification, the common business plan focus in entrepreneurial education is more in line with a creation approach than with a value creation or venture creation approach, since writing a business plan by itself does not create value to external stakeholders, (Honig, 2004). Instead the business plan often becomes a deliverable to the teacher, and would not survive first contact with the assumed customers. In the same view, Jones and Penaluna (2013) argue that project based learning is also an example of a creation approach since the artifacts are primarily used for teacher evaluation, not for creating value to outside stakeholders. Service-learning is a rare example of a value creation approach where value is created to the surrounding community. This progression model puts value creation at its center.

With reference to the above proposed progression models, we may affirm that coming up with an integrated model that puts together the diverse values suggested is even richer although it may not evidently simple to achieve. However, Lackéus (2015) has proposed four steps leading to the formation of an integrated progression model. In the first step, an embedded approach is recommended where learners get to take action by addressing societal challenges and everyday problems based on their own interest and ideas, integrated into the core subjects of school rather than treating entrepreneurship as a separate subject. This spurs creativity, engagement and selfefficacy, but also uncertainty and ambiguity which can be a negative experience initially. Here the students can be turned into teachers, telling their peer students about what they learned through the process. Such oral articulation of actions taken and resulting insights can facilitate the deep learning process significantly according to Russian psychologist Galperin as cited by Haenen (1996). The embedded approach leans on the wide definition of entrepreneurship.

According to Lackéus (2015), in the second step of education such as secondary school (but not necessarily), a crossroad comes where most learners continue with the embedded approach but with more emphasis on acting on curriculum knowledge. Some learners make an active choice leading to a separate subject approach where business language and terms are added and the aim is narrowed into creating a venture, for example the very common Young Enterprise approach (Dwerryhouse, 2001). In the second step the stakes are raised and the risk for failure increases, allowing learners to develop perseverance and a constructive attitude towards failure. The separate subject approach leans on the narrow definition of entrepreneurship, (Lackéus, 2015).

In the third step the embedded approach becomes more skillbased and underpinning entrepreneurship theory is made explicit allowing students to reflect on the theoretical base of 
their acting entrepreneurially. This allows for the development of entrepreneurial passion and perhaps even entrepreneurial identity in some learners. The value created as formal part of curriculum can be so significant that it sometimes leads to real-life economic growth for the collaboration partners outside the educational institution. The final output of the embedded approach is more entrepreneurial people creating new kinds of value in all domains of society and all walks of life, (Lackéus, 2015). In the very third step separate subject approach, theory is also made explicit. As learners approach the end of their education it is possible to add the goal of creating a sustainable venture with intention to incorporate after graduation, that is; the sustainable venture creation approach, (Lackéus, 2015). This adds to the engagement levels of students and also results in some of these ventures actually becoming real- life start-ups creating jobs and economic growth, (Barr et al, 2009). The final output of the separate subject approach is actual entrepreneurs creating ventures within or outside established organizations, but also entrepreneurial people creating growth and value in all domains of society. According Lackéus (2015) such a unified model would incorporate many of the dimensions deemed to be central to achieving progression in entrepreneurial mentorship.

\section{RESEARCH DESIGN AND METHODOLOGY}

The research used the mixed method approach and specifically employed the Concurrent triangulation design. Qualitative and quantitative data was concurrently collected in one phase. This design is a form of mixed methods design in which the researcher converged or merged quantitative and qualitative data in order to provide a comprehensive analysis of the research problem. The researcher selected this design because it allows the collection of both forms of data at roughly the same time and then integrated the information in the interpretation of the overall results after a separate analysis. The target population was all undergraduate students at Kwame Nkrumah University of Kabwe-Zambia who are undergoing the process of being prepared for life in society, Lecturers and Administrators.

The study intended to cover $20 \%$ of the undergraduate students, that is; $10 \%$ of the full time students and $10 \%$ of the part-time students. That is about 300 respondents in number. $10 \%$ of the staff interviewed: 20 lecturers and 4 administrators. Therefore, the sample size set was 30\% (representative of the target population), which makes a total of 324 respondents. This study technically chose the $3^{\text {rd }}$ and $4^{\text {th }}$ year students who have substantial experiences at the University and among these students, simple random sampling was employed. Random sampling for Lecturers and purposive sampling for Administrators were used respectively. It is important to note that respondents other than undergraduate students were chosen based on their influence on the process of mentoring undergraduates in entrepreneurship. This implies that, a number of staff members were a viable source of data for this research as indicated above. The researcher prepared to administer structured questionnaires to the undergraduate students, the use of in-depth interview guides on Lecturers and Administrators. Some unstructured interviews were also conducted on some lecturers and some administrators. These interviews involved closed ended and generally open-ended questions that are few in number and intended to elicit views and opinions from the participants. Samples of the opted for instruments are included in the appendices

\section{FINDINGS}

\section{Teacher Education Training Curriculum in promoting entrepreneurship}

About 5\% $3^{\text {rd }}$ year students said students at the university receive mentorship in entrepreneurship on an often basis, $4 \%$ said it is rarely practiced and $41 \%$ said students at the university are never mentored. For $4^{\text {th }}$ year students, $14 \%$ confirmed that they often practice mentorship, $16 \%$ stated that the mentorship is rarely done and $70 \%$ said mentorship of students in entrepreneurship is never practiced at the University. The frequency or extent of mentorship of undergraduate students in entrepreneurship is mostly determined by the structure of the curriculum in application at the university. From the administration, it is revealed that the university uses the General Education Curriculum for training students.

\section{Gaps in promoting entrepreneurship}

Student respondents expressed a number of challenges vis-àvis promoting in entrepreneurship and among them are: about $88 \%$ respondents expressed lack of mentorship in entrepreneurship, $89 \%$ said they lack adequate information on entrepreneurship, 93\% indicated that the challenge is that entrepreneurship was not considered as an overarching course for all categories of studies at the University and 91\% mentioned that they are lacking qualified personnel to mentor them in entrepreneurship. In addition, 90\% respondents highlighted lack of material support, 69\% mentioned unavailability of financial support, $27 \%$ talked of lack of industrial attachment, and 58\% respondents said students lacked motivation and hence poor entrepreneurial attitude.

Staff responded expressing a number of challenges on mentorship in entrepreneurship. From the total of 19 staff who responded; all stated that the university has challenge financially, $84 \%$ responded that there is lack of qualified mentors, 68\% expressed the poor entrepreneurial attitude, $63 \%$ acted in response to lack of practical involvement, while $53 \%$ reaffirms to no facilities and material resources in the university.

\section{Bridging the Gap Teacher Education in Promoting Entrepreneurship}

Among different ways of promoting entrepreneurship suggested by students on how to improve mentorship of 
students in entrepreneurship as reviewed in the findings are: about $23 \%$ mentioned revising the curriculum, $94 \%$ mentioned introducing entrepreneurship as a compulsory course, $91 \%$ mentioned provision of qualified mentors, $16 \%$ securing grants and loans for students, $25 \%$ promoting industrial attachment and $63 \%$ mentioned motivating of students.

All members of staff suggested that the curriculum catering for tertiary education be revised putting entrepreneurship as a compulsory course and training of mentors should be conducted as the strategies to improving the mentorship. In addition, all staff suggested that financial and material support must be increased in entrepreneurial activities. About $47 \%$ suggested linking students with actual entrepreneurs and $31 \%$ members of staff highlighted that engagement of students in entrepreneurial research can be considered as a best strategy. Finally all staff expressed that financial and material support is one of the key strategies.

\section{DISCUSSION}

\section{Teacher Education Training Curriculum in promoting Entrepreneurship}

As curriculum entails the plan for the totality of all the learning experiences (Daka and Changwe, 2020; Daka, Banda and Namafe, 2017), training of students in entrepreneurship may then be considered as a component of it. Mentorship in entrepreneurship would consequently be discussed through the way students` training programs are structured. As stated earlier under reviewed related literature, the way teachers are prepared has a big bearing on the type of pupils they will produce throughout their teaching careers. The study established that only $13 \%$ of the respondents stated that they received mentorship in entrepreneurship on an often basis, $7 \%$ stated that they were rarely mentored and $80 \%$ expressed that they were never mentored.

The Primary Teachers ${ }^{e e}$ Diploma Revised Curriculum (GRZ, 2016) clearly shows that acquisition and development of knowledge, skills and values in entrepreneurship and I.C.T is at the centre and this is aimed at increasing teacher productivity prospects in society. Again referring to the review of related literature, we notice that the Secondary School Teachers' Education Training curriculum also did not treat the aspect of entrepreneurship as an exception but as cardinal element to teacher training. It is aimed at producing teachers who would be adequately equipped with knowledge and skills in entrepreneurship and information and communication technology, teachers who would transmit it to young learners using a variety of approaches.

Referring to the findings of this study, it is established that the element of entrepreneurship that was in the teacher education training curriculum was actually directed towards benefiting primary and secondary school pupils and not teachers. In the same vein, Lecturer $\mathrm{Z}$ stated that the students at the university are only taught how to impart elements of entrepreneurship to the pupils they would be handling but the system had no formal and overarching provision that was seeking to transform these students into entrepreneurs. This implies that mentorship in entrepreneurship was inclusively linked from primary school education to secondary school education but there existed a missing link, a lacuna between secondary school education and tertiary education. It was this missing link that resulted into mass unemployment. This was affirmed by Ngoma (2012) as he states that it is worth noting that about 300,000 youth enter the labour market each year from the education system yet only about 15,000 get formal sector jobs. The economic and social impact of the high unemployment rate is huge.

According to the GRZ (2011), Zambia suffers a skilledworker gap in manufacturing caused by the mismatch between the skills offered by training institutions and those demanded by industry. The level of self-starting entrepreneurs was also low especially among graduates. The economy was in effect throwing away the goods and services that the unemployed workers could have produced while the social impact was unquantifiable as no figure could convey the human and psychological pain of long periods of persistent involuntary unemployment (Ngoma, 2012).

According to the findings of this research, all the lecturers that were interviewed were entrepreneurs to some extent but only three confirmed to have received training in entrepreneurship prior to their first deployment and this implies that among the reached out staff, the said respondent was the only professional entrepreneur. The rest of the staff are entrepreneurs but not in the professional sense. Others have considered carrying out personal researches on entrepreneurship, one other staff confirmed to have been taking online courses in entrepreneurship out of personal interest. Training lecturers in entrepreneurship is cardinal, it follows that if they are not trained in this domain, they cannot mentor students in entrepreneurship; they cannot give what they do not have.

In promoting entrepreneurship, there is a connotation of practicability through assessment importantly attached to it (Daka, Chipindi and Mwale, 2020; Mulenga - Hagane, Daka, Msango, Mwelwa and Kakupa, 2019). This further prompted the researchers to find out from student respondents about entrepreneurial activities or projects that the University is running as an Institution so as to determine students` involvement in the practical part of the said mentorship. From the findings, it is established that in fact all the entrepreneurial activities mentioned are as a matter of fact speculative expressions and this evidently suggests that few or no students were actively involved in those entrepreneurial activities that the university was running. Involving them in the mentioned activities would have counted as practical mentorship in entrepreneurship. 


\section{Gaps in promoting entrepreneurship}

The findings established that respondents faced a number of challenges regarding the practice of mentorship in entrepreneurship. $89 \%$ of the responses gathered indicated that they lacked mentorship in entrepreneurship. This clearly suggests the majority does not access mentorship of the said sort from the university staff and that only $11 \%$ of the respondents are mentored. Out of $11 \%$ of students who access mentorship in entrepreneurship, it is important to bear in mind that the very percentage has to be split into those that accessed mentorship on an often basis and those that rarely accessed it. Lack of mentorship is directly linked to lack of qualified mentors in entrepreneurship. 91\% expressed that there was lack of qualified mentors at the institution. As at now, only lecturers in Business studies are the ones who support and mentor students on entrepreneurship. In an interview, one of the staff members added on as he said:

"We lack support system where lecturers would be trained and qualify to become mentors. We cannot give what we don't have. It is therefore necessary that a support system be envisaged if qualified mentors are to be secured for the university."

In support of the view above, Uthman (2016) and Kakupa, Tembo and Daka (2015) stress that the primary obstacle is that there is lack of lecturers with practical entrepreneurial training and consciousness. Majority of the lecturers still do not have enough knowledge about the aims, contents and work method of entrepreneurship education. With the same view, Konayuma (2009) adds in stating that in the case of Zambia, among various challenges being faced in the provision of entrepreneurial education is the problem of inadequate entrepreneurship trainers.

Carefully analysing the quotes above, we note an aspect of practical training in entrepreneurship. Under the previous discussion were we looked at the curriculum in practice with entrepreneurship, we have discovered that the little training that a few students receive is theoretical other than practical. This implies that those who act as mentors may probably be lacking practical entrepreneurship training. Practical involvement of students in entrepreneurial projects is indispensable; $27 \%$ of respondents highlighted that there is lack of practice of entrepreneurial ideas that they acquire and that they are not linked with firms or companies for adequate mentorship.

Even if more than $90 \%$ of respondents were willing to be mentored in entrepreneurship, findings have established that entrepreneurship was not offered as a cross cutting course. This challenge denied the mass of students that were not under business studies from accessing mentorship in entrepreneurship, this was recognized by $93 \%$ of the responses. Commenting on the same challenge, Uthman (2016) recognizes that non-inclusion of entrepreneurship program in the general school curricula was a real challenge.
Poor entrepreneurial attitude or culture is yet another challenge that the study has established. $80 \%$ indicated that among students, there exists a poor attitude towards entrepreneurship. Similarly, this agrees with what Uthman (2016) identifies as one of the challenges when he states that there is poor societal attitude towards technical and vocational education development. A number of respondents stated that, commonly a lot of students entertained the attitude of expecting to find formal employment upon graduating, which is not exactly what was happening. Masses have been finding themselves unemployed and that becomes precarious to survive without empowerment in entrepreneurship knowledge, skills and values prior to their integration into society as skilled labour. This would eventually result into high levels of poverty, increased crime rate and denying the country development. And if thousands of trained graduates remain unemployed, in this context, it logically follows that their skills acquired were not put to use, implying that society and its government were losing out a lot of contributions.

$90 \%$ highlighted that unavailability of material support was one of the major challenges vis-à-vis promotion of entrepreneurship. Respondents indicated that there were no materials and facilities to facilitate promotion in entrepreneurship. This resonated with the way training of students in entrepreneurship was done at the university as established by the findings of the study. If facilities and materials were adequately available, the university would most probably consider practically mentoring students. However, through interviews, some respondents revealed that the university had at least enough land.

Linked to the challenge discussed above was lack of financial support, this was expressed by $69 \%$ of the respondents. Running of activities that facilitate mentorship in entrepreneurship necessitates a life line of financial support. In fact, for materials to be procured, finances act as means. In the process of mentorship, there comes a moment when students have to be allowed to practically apply the entrepreneurial knowledge and skills acquired through establishing and running their own ventures. Funds are actually an indispensable requirement for establishing and running the said ventures in view of completing successful mentorship in entrepreneurship. In the same line of thought, Barringer and Ireland (2006) outline the importance of getting finances or funds when setting up a business venture. They argue that the need to raise money catches some entrepreneurs off guard. Many entrepreneurs start their firms with the intention of funding all their needs internally. Commonly though, entrepreneurs discover that operating without investment capital or borrowed money is more difficult than they anticipated. They further argue that because of this, it is important for entrepreneurs to understand the role of investment capital in survival and subsequent success of a new firm. 


\section{Bridging the Gap Teacher Education in Promoting Entrepreneurship}

A curriculum is the totality of all the planned learning experiences. It is a plan for the practice of education and it can also be referred to as the heart of the school systems. If the provision of mentorship in entrepreneurship is to be enhanced, it is important to consider going back to the drawing board, revising the curriculum (plan for education). It is inevitable that the curriculum developed matches the needs, aspirations and expectations of society or rather the population for which it is prepared for and in the case of the contrary, the curriculum is doomed irrelevant. This argument actually tarries with what UNESCO (2016), Daka, Banda and Namafe (2017) and Daka, Namfe and Katowa - Mukwato (2019) state that in order to ensure that students in Zambia acquire the skills, knowledge, and values they need for their personal fulfillment as well as for the realization of the country's social and economic development, and particularly in the context of its Vision 2030, a curriculum aligned to the demands of the current labor market must be designed.

According to the findings, the study has established that there exist a missing link in the promotion of entrepreneurship between secondary school education and tertiary education. Primary school educations just like secondary school education had been provided for in the curriculum vis-à-vis promotion of entrepreneurship but not at tertiary level. Those who access entrepreneurship at tertiary level were few and most of them were from the business studies. Making the promotion of entrepreneurship inclusive or cross cutting may be considered as preliminary to the strategies for bridging the gap in entrepreneurship. In the same line of thought, $30 \%$ of respondents had recognized revising the curriculum ensuring that mentorship of entrepreneurship was provided as a compulsory course. $100 \%$ of the staff suggested revising the curriculum. Commenting on this, in an interview, one of the staff members added that to achieve introducing mentorship in entrepreneurship as a compulsory course at tertiary level requires insurmountable political will and coherent leadership deliberations. It is anticipated that entrepreneurial knowledge, skills and values would help solve contemporary social challenges such as mass unemployment, poverty and eventually transform lives of citizens positively.

In view of three lecturers, after revising the plan for education, it is necessary to ensure the availability of human resource for a successful implementation. Training mentors would be another priority. Lecturers need to be empowered by a support system which allows them to study and become qualified mentors. All the staff (100\%) and 90\% of students recognized this as a key strategy. Seminars and workshops may be held to constantly make sure that mentors move with the changes that are taking place in the context of entrepreneurship education. This agrees with what a member of staff stated in an interview when she said it is important that lecturers become adequately equipped with entrepreneurial knowledge, skills and values since they (lecturers) cannot offer what they do not have. Scott (2019) and Daka (2019a) equally shares the same view; he states that training of mentors must consider familiarizing them with policies and programs affecting universities or institutions of higher learning. Supplementing on the above discussed strategies, it is important to note that for a successful implementation of the suggested strategies, there is need for political will to propel that through policies that the Ministry of General Education may formulate. In the same line of thought and as quoted earlier, UNESCO`s review highlights that the challenges the system has concerns the implementation of education policies and programs, which is often hampered by ineffective accountability mechanisms, poor regulatory frameworks, weak enforcement of laws and regulations, and, to some extent, resourcing issues, such as the shortage of skilled staff.

Adding more emphasis to this view, the review by UNESCO (2016: 281) stress by stating that:

"The Government must increase funding for TEVET to at least between 3 to 4 per cent of its education budget, which is the SADC average, as severe underfunding has been noted in this domain. In the process, industry, TEVET providers, and TEVETA should collaborate to develop a more relevant curriculum and to make TEVET more responsive to labour market demands. In fact, a relevant TEVET curriculum is a vital requirement that was raised by different stakeholders throughout the review process. Therefore, in order to ensure that TEVET plays its role as a driver of economic and income growth, as the Government intends, the country must ensure that the design and delivery of the curriculum are led by industry."

The Technical Education, Vocational and Entrepreneurship Training (TEVET) is the policy that principally anchors the element of entrepreneurship in the Zambia education system. Stepping up funding for its implementation at least up to an average percentage would positively affect mentorship of students in entrepreneurship. The quote above has reemphasized on partnering with non-public stakeholders and industry in view of maximizing investment in the policy implementation. At the same time, the aforementioned partnership would in turn create an environment for practical mentorship for students and this mentorship would indubitably be led by contemporary demands of the labor market given that the industry is up to date with every change that may be effected.

Financial support is a necessity for the establishment and sustenance of entrepreneurial projects. The university should consider procuring or lobbing for funds for establishing and sustaining entrepreneurial projects. The university could solicit funds that can be provided to students as loans and lobbing for firms that would be willing to support the mentorship of students through grants. All staff interviewed highlighted how critical the financial support system is to both 
running university entrepreneurial projects and the mentorship process in entrepreneurship.

The researchers agrees with the claim that development begins with the mind. Universities are key places where competent minds are shaped and generally, it may be argued that universities are the principal source of the skilled leadership and technical expertise needed to guide national development (Daka, 2019b; Daka, Banda \& Namafe, 2020). These human resources constitute fundamental inputs for national capacity building that is a requirement for development and economic growth. Universities would easily achieve the development of an entrepreneurship rich culture through changing the mentalities of trainees.

\section{CONCLUSION}

From the findings of this study, it is evident that the curriculum that was being used to train students did not treat entrepreneurship as a compulsory course but only appears as a component under the school of business studies. This implies that the element of entrepreneurship that was in the teacher education training curriculum was actually directed towards benefiting primary and secondary school pupils and not those being trained as teachers. This consequently resulted into a lacuna between secondary school education and tertiary education regarding the provision of mentorship in entrepreneurship. This subsequently reveals that the general education curriculum for teacher training is not inclusive in the provision of mentorship in entrepreneurship to students.

As discussed in the previous chapter, promotion of entrepreneurship has an element of practical involvement inseparably linked to it, on the contrary, it has been established that another lived challenge in this consisted the inability to actively and practically involve students in university entrepreneurial projects or activities. This re-echoes the above conclusion which highlights that the little promotion in entrepreneurship that was being done at the university was actually theoretical and not practical. If the university had not adequately established entrepreneurial projects in which students could beneficially be involved or manage to successfully establish links with industry and actual entrepreneurs, it is precarious to practically mentor students to the desired standard.

Discussing bridging the gap, there is need to revise of the teacher education curriculum. According to the study, this should be done in such a way that the curriculum in application for training students treats promotion of entrepreneurship inclusively. In other words, this implies that the component of the said entrepreneurship shall become a cross cutting or compulsory element in the training of students regardless of their respective courses of study. The component of entrepreneurship to be inclusively added to the curriculum must be of a specific nature; it must be goal oriented so that apart from propelling productivity, creativity and innovativeness, the set goals also serve as an effective tool for evaluation.

Development of human resource should strategically be devised. It is this human resource that will carry out the implementation of the revised curriculum if intended goals, aims and objectives are to be attained. The human resource should be formed as qualified mentors and allowed to accumulate substantial experience in the context of entrepreneurial knowledge, skills and values.

Among other ways of bridging the gap in teacher education for the promotion of entrepreneurship include practically involving students in entrepreneurial projects/activities in view of nourishing their mentorship has been deemed essential and linking students to actual entrepreneurial (industry) to allow the sharing of diverse experiences that include successes as well as challenges. This has simply been referred to as linking students with industry allowing them to put into practice the knowledge, skills and values they acquire other than just being theoretically mentored. There is need for a study to empirically prove that teachers teaching entrepreneurship needs practical industry experience.

\section{REFERENCES}

[1] Barr, S. H, Baker, T. and Markham, S. K., (2009). Bridging the Valley of Death: Lessons Learned From 14 Years of Commercialization of Technology Education. Academy of Management Learning \& Education, 8, 370-388.

[2] Barringer, B. R. and Irenland, R. D., (2006). Entrepreneurship Successfully Launching New Ventures. New Jersey: Pearson Education Inc.

[3] Becker, G. S., (1993). Human Capital: A Theoretical and Empirical Analysis with Special Reference to Education $\left(3^{\text {rd }}\right.$ ed). Chicago, IL: University of Chicago Press.

[4] Clutterbuck, D., (2002). Couching and Mentoring. Bunham: Clutterbuck and Associates.

[5] Daka, H. (2017). Social Life Skills in the Era of HIV/AIDS among Learners in Learning Institutions, Muka Graphics and Printing Hub, Lusaka.

[6] Daka, H., Banda, S. S. and Namafe, C. M. (2017). Course management, Teaching and Assessing Undergraduates at the Medical School of the University of Zambia. International Journal of Humanities Social Sciences and Education. 4 (10), $10-$ 18.

[7] Daka, H., Namafe, C. M. and Katowa - Mukwato, P. (2019). Perspectives on Teaching Approaches and the Grade Point Average Attainment of Undergraduate Medical Students at University of Zambia. International Journal of Humanities Social Sciences and Education. 6 (12), 75-82.

[8] Daka, H. (2019a). Understanding the Correlation between Institutional Characteristics and Academic Performance: A case of Undergraduate Medical Students at University of Zambia. Journal of Lexicography and Terminology. 3 (2), 96 - 116.

[9] Daka, H. (2019b). Perspectives on Course Management, Teaching and Assessment of Undergraduate Programmes at the Medical School of the University of Zambia. (PhD Thesis, University of Zambia, Lusaka).

[10] Daka, H., Banda, S. S., \& Namafe, C. M. (2020). The Relationship between Course Management and Examination Attrition Rates among Undergraduate Medical Students at the University Of Zambia. International Journal of African Higher Education, 7(1), $97-112$.

[11] Daka, H., Chipindi, F. M. and Mwale, M. (2020). The Relationship between Assessment Practices and Students' 
Academic Performances. A Case of Undergraduate Students at the Medical School of the University of Zambia, 2008 - 2016. Zambian Journal of Educational Management, Administration and Leadership, 1 (1), 143 - 156

[12] Daka, H. and Changwe, R. (2020). An Exploration of Education Quality in the Light of the Grade Point Average and Examination Attrition Rate. International Journal of Humanities Social Sciences and Education. 7 (6), 196-207.

[13] Dwerryhouse, G., (2001). Experiential Learning: http://www.researchgate.net .

[14] Gibb, A. A. Haskins, G. \& Robertson, I., (2013). Leading the entrepreneurial university: Meeting the entrepreneurial development needs of higher education institutions. In Universities in Change. New York: Springer.

[15] Gimmon, E., (2014). Mentoring as a Practical Training in Higher Education of Entrepreneurship. Norway: Bergen.

[16] Go Zambia Jobs. (2018). Formal employment in Zambia. Lusaka: http://www.gozambiajobs.com

[17] Government of the Republic of Zambia. (2018). Zambia in Figures 2018. Lusaka: Central Statistics Office Information and Dissemination Division.

[18] Government of the Republic of Zambia. (1996). TEVET Policy. Lusaka: MOE.

[19] Government of the Republic of Zambia., (2011). Sixth National Development Plan 2011-2015 "Sustained Economic Growth and Poverty Reduction". MNPD.

[20] Government of the Republic of Zambia., (2016). Primary Teachers' Diploma Revised Curriculum: Ministry of General Education (MoGE). Lusaka: Curriculum Development Centre.

[21] Haenen, J., (1996). Outlining the Teaching - Learning Process: Entrepreneurship: $\quad$ http://www.dspace.library.uu.nl.

[22] Honig, B., (2004). Entrepreneurship Education: Toward aModel of Contingency-Based Busiess Planning: http://www.entrepreneurship-education-toward-a-model.pdf.

[23] Jones, C. \& Penaluna, A., (2013). Moving beyond the business plan in enterprise education. Education+ Training, 55. Journal of Small Business and Enterprise Development. 19 (3).

[24] Kakupa, P., Tembo P., and Daka, H. (2015). Linking Teacher Effectiveness to School Performance: Evidence from Rural DaySecondary Schools in Western Province of Zambia. Zambia Journal of Teacher Professional Growth. 2 (2), 17-30.

[25] Konayuma, G. S., (2009). National curriculum Review Symposium Relevance of Entrepreneurship Training in a Market Driven Economy. Lusaka: Ministry of Science and Vocational Training. Retrieved from: http://www.scribd.com/doc/16299038/Relevanceof Entrepreneurship-Training-in-a-Market-Driven-EconomyKonayuma.

[26] Lackeus, M., (2015). Entrepreneurship in Education: Entrepreneurship360 Background Paper. Middleton: Routeledge.

[27] Mulenga - Hagane, M., Daka H., Msango H. J., Mwelwa K and Kakupa P. (2019). Formative Assessment as a means of Improving Learner Achievement: Lessons from selected Primary Schools of Lusaka Zambia. Journal of Lexicography and Terminology. 3 (1), $33-54$.

[28] Netcoh, S., (2016). The Strengths and Limitations of Human Capital Theory in Educational Research and Policy Making. Retrieved from: http://www.blog.uvm.edu

[29] Ngoma, I., (2012). Trade Unions-Political Party Relations Under Changed Political and Economic Realities. Lusaka: Economic Association of Zambia.

[30] Scott, L. M., (2019). Enhancing Principal's Skills through Suitable Mentoring Programs. NAESP. Iscott1120@comcast.net.

[31] Sullivan, R., (2000). Entrepreneurial Learning and Mentoring. International Journal of Entrepreneurial Behaviour and Research, $6(3)$.

[32] Sullivan, R., (2000). Entrepreneurial Learning and Mentoring. International Journal of Entrepreneurial Behavior \& Research, 6 (3).

[33] Sweetland, S. R., (1996). Human Capital Theory: Foundations of a Field of Inquiry. Retrieved from: http://www.researchgate.net.
[34] Unachukwu, G. O., (2009). Issues and Challenges in the Development of Entrepreneurship Education in Nigeria. Retrieved from http://www.ajol.info/index.php/afrrev/article/viewFile/51153/3983 o.

[35] UNESCO. (2016). Zambia Educational Policy Review: Paving the Way for SDG 4 - Education 2030. ED-2016/WS/37.

[36] Uthman, A., (2016). Entrepreneurship and Leadership. Retrieved from: http://www.researchgate.net.

[37] White, A., (2012). The Guardian: The Biggest Challenge Facing Graduate Jobseekers Today. Retrieved from: http://www.theguardian.com.

[38] Zambia Educational Curriculum Framework Review (ZECFR). (2013). Educational Curriculum Reform. Lusaka: MoE. 